\title{
Free Fructose in Human Cerebrospinal Fluid*
}

\author{
H. Linton Wray and Albert I. Winegrad
}

George S. Cox Medical Research Institute and the Department of Medicine, University of Pennsylvania, Philadelphia

Received June 28, 1966

Summary. The presence of free fructose in human cerebrospinal fluid has been demonstrated by enzymatic analysis and high voltage paper electrophoresis. In 39 of 40 patients the cerebrospinal fluid fructose concentration exceeded that in plasma. A linear correlation $(r=$ +0.88 ) was observed between cerebrospinal fluid fructose and glucose concentrations. Present evidence suggests that neural tissues are the source of cerebrospinal fluid fructose, and that fluctuations in cerebrospinal fluid fructose concentration mirror fluctuations in the neural concentrations of this hexose. These observations suggest that increased activity of the sorbitol pathway may exist in the neural tissues of patients with diabetes mellitus similar to that recently observed in tissue from animals with experimental diabetes.

\section{Fructose libre dans le liquide cérébro-spinal humain.}

Résumé. La présence de fructose libre a été démontrée dans le liquide céphalo-rachidien humain par analyse enzymatique et électrophorèse à haut voltage sur papier. Dans 39 cas sur 40 la concentration en fructose du liquide céphalo-rachidien dépassait celle du plasma sanguin. Nous avons observé une corrélation linéaire $(r=+0.88)$ entre les concentrations de fructose et du glucose dans le liquide céphalo-rachidien. Nos connaissances actuelles suggèrent que le fructose du liquide céphalo-rachidien est produit par les tissus nerveux et que les fluctuations de la concen. tration de fructose dans ce liquide reflètent les fluctuations de la concentration de cet hexose dans les tissus nerveux. Ces observations nous permettent de croire que la réduction du glucose en sorbitol et son oxydation subséquente en fructose sont plus actives dans le tissu nerveux de malades diabétiques, tout comme cela a été récemment observé pour le tissu nerveux d'animaux atteints de diabète expérimental.

Freie Fructose in der Cerebrospinalflüssigkeit des Menschen

Zusammenfassung. Das Vorhandensein von Fructose im Liquor cerebrospinalis beim Menschen wurde enzymatisch und mit Hochspannungselektrophorese auf Papier nachgewiesen. Die cerebrospinale Fructosekonzentration überstieg in 39 von 40 Fällen diejenige im Blutplasma. Es bestand eine vorzügliche Korrelation $(r=+0.88)$ zwischen den Konzentrationen von Fructose und Glucose im Liquor. Unsere jetzigen Kenntnisse deuten darauf hin, daß das Nervengewebe den Bildungsort der Liquor-Fructose darstellt und daß Schwankungen in der Konzentration der Fructose im Liquor Schwankungen in der neuralen Konzentration dieser Hexose widerspiegeln. Diese Beobachtungen sind mit der Möglichkeit einer vermehrten Umwandlung von Glucose über Sorbitol zu Fructose im Nervengewebe von Patienten mit Diabetes mellitus vereinbar, ähnlich wie dies bei Tieren mit experimentellem Diabetes beobachtet wurde.
In 1937 HUBbaRd and Russell [3] reported the demonstration of free fructose in human cerebrospinal fluid by using the resorcinol method of RoE [10] and applying a correction for the interfering color that resulted from the presence of glucose in their samples. Fructose concentrations ranging from 0.2 to $7.8 \mathrm{mg} \%$ were observed in cerebrospinal fluid samples from 30 patients with and without clinical evidence of neurological disease. For technical reasons HubBard and Russeut [3] felt that little significance could be attached to the individual values for blood fructose in their series, but it was apparent that in almost every patient the level of fructose in cerebrospinal fluid exceeded that in blood. These intriguing observations have been neglected for almost 30 years because of scepticism concerning the specificity of the method employed and because of the inexplicable discrepancy between the blood and cerebrospinal fluid fructose concentrations.

* Supported in part by USPHS Grant No. AM 04722-06 from the National Institute of Arthritis and Metabolic Diseases, and by Research Career Development Award No. GM 6405-02 of the National Institutes of Health.
In 1964 Stewart and Passonneat [14] found substantial levels of free fructose in dog and rabbit peripheral nerve and in mouse brain. Subsequently GaBBaY et al. [1] reported that the levels of fructose and sorbitol in peripheral nerve and spinal cord from alloxan diabetic rats were markedly increased. They [1] suggested that "a possible consequence of the accumulation of sorbitol and fructose and their inability to escape from the intracellular compartment may be a harmful osmotic effect", and raised the possibility that this might contribute to the pathogenesis of some forms of diabetic neuropathy.

These recent observations led us to re-examine the findings of HubbaRd and Russer [3] with more specific techniques to determine whether fructose was in fact present in human cerebrospinal fluid, and whether alterations in its concentration might reflect the derangements in metabolism observed in neural tissues from animals with experimental diabetes.

\section{Methods}

Cerebrospinal fluid was obtained by lumbar puncture from 42 hospitalized patients in whom the procedure was indicated for other reasons. In 29 instances 
the patients were to receive spinal anesthetics for elective surgical procedures. In 40 patients a heparinized sample of venous blood was obtained at the time of lumbar puncture. The samples were kept in ice from the time of collection. Plasma and cerebrospinal fliud. samples were assayed immediately or frozen and assayed within 48 hours. Protein-free (Somogy ) [13] filtrates were prepared resulting in a 5:1 dilution of the cerebrospinal fluid samples, and a 20:1 dilution of the plasma samples. Aliquots of these filtrates, usually $0.25 \mathrm{ml}$, were assayed for glucose and fructose by the enzymatic method of KLotzsch and Bergmeyer [6] using enzymes obtained from Boehringer and Sons. In this technique glucose and fructose in the sample are phosphorylated to the corresponding hexose-6-phosphate by treatment with yeast hexokinase, ATP, and $\mathrm{Mg}^{++}$. Glucose-6-phosphate dehydrogenase from yeast is added in the presence of TPN and the increase in optical density at $340 \mathrm{~m} \mu$ determined. The addition of phosphoglucose isomerase then catalyzes the conversion of fructose-6-phosphate to glucose-6-phosphate and the oxidation of the latter results in a second rise in optical density at $340 \mathrm{~m} \mu$. Under the conditions employed in these experiments there was no increase in optical density at $340 \mathrm{~m} \mu$ with samples of pure fructose prior to the addition of phosphoglucose isomerase. A clearly defined platean was always observed 10 to 16 minutes after the initial addition of glucose-6-phosphate dehydrogenase when filtrates of cerebrospinal fluid or plasma were assayed. Controls were also included to correct for the presence of any preformed glucose-6-phosphate or fructose-6-phosphate in the samples but these were rarely significant. With the glucose-6-phosphate dehydrogenase preparation employed in this study, 1 micromole of TPNH was formed for each micromole of glucose-6phosphate added.

By this technique fructose could be determined in cerebrospinal fluid in concentrations as low as 0.50 $\mathrm{mg} \%$. Because of the greater dilution required to produce protein-free filtrates of plasma, values for plasma fructose below $2.0 \mathrm{mg} \%$ were not assayable.

\section{Results}

Signifieant quantities of fructose (>0.50 $\mathrm{mg} \%$ ) were found in every one of the 42 cerebrospinal fluid samples examined with values ranging from 1.8 to $13.0 \mathrm{mg} \%$. The presence of fructose in cerebrospinal fluid was confirmed by high voltage paper electrophoresis of deproteinized samples using the conditions described by MABRY et al. [7]. Using a $0.1 \mathrm{M}$ borate buffer at $\mathrm{pH} 9.2$ two spots were observed when the papers were stained with diphenylamine-p-anisidine reagent, one corresponding to glucose and one to fructose and galactose. On electrophoresis in borate buffer at $\mathrm{pH} 7.3$ which permits a better separation of fructose and galactose the second spot had the mobility of fructose. The non-glucose spot in both instances gave the reddish color of a ketohexose when stained with naphthoresorcinol [8].

As shown in Figure 1, the plasma fructose concentration in 29 of the 40 plasma samples obtained at the time of Iumbar puncture was less than $2.0 \mathrm{mg} \%$ and therefore unassayable by this technique. In the remaining 11 samples the plasma fructose concentration ranged from 2.2 to $4.6 \mathrm{mg} \%$. As indicated in

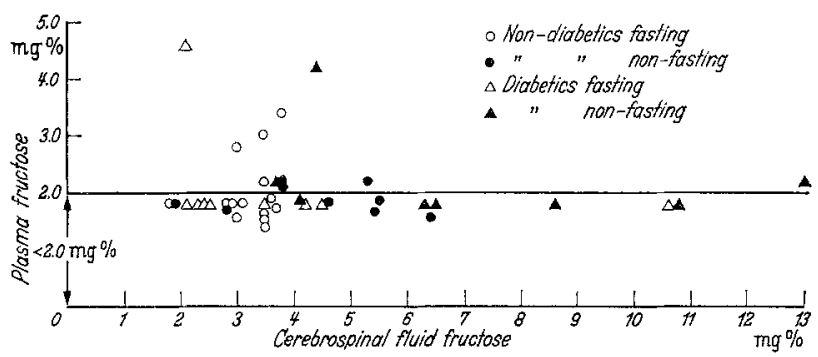

Fig. 1. Comparison of plasma and cerebrospinal fluid fructose concentrations

Fig. 1, the cerebrospinal fluid fructose concentration exceeded the plasma fructose concentration in 39 of the 40 patients in whom a comparison was possible. The single exception was a 68 year old diabetic who had been fasting for 22 hours prior to lumbar puncture and whose plasma fructose concentration was $4.6 \mathrm{mg} \%$ at a time when the cerebrospinal fluid fructose concentration was $2.1 \mathrm{mg} \%$.

As shown in Figure 2, there was a linear relationship (correlation coefficient +0.88 ) between the cerebrospinal fluid fructose and glucose concentrations in the 42 samples studied.

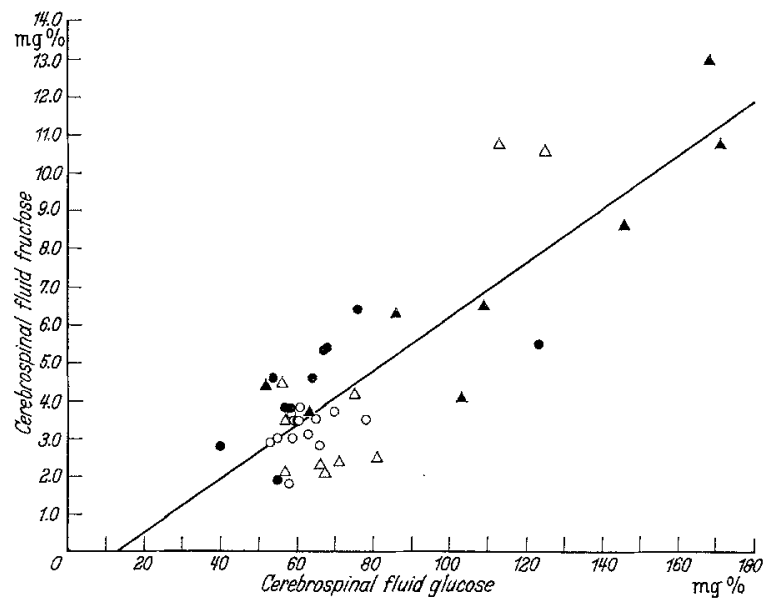

Fig. 2. The significance of the symbols is as described in Figure 1. Line fitted by the method of least squares

\section{Discussion}

PARK et al. [9] observed that in adult rats $D$-fructose infused intravenously does not cross the "blood- 
brain barrier" to a measurable extent. The presence of fructose in human cerebrospinal fluid in concentrations generally greater than that found in plasma therefore suggests that neural tissues are the source of cerebrospinal fluid fructose.

Both aldose reductase and sorbitol dehydrogenase activities are known to be present in rat peripheral nerve [11].

$$
\begin{gathered}
\text { Glucose }+\mathrm{NADPH}+\mathrm{H}^{+} \rightleftharpoons \text { Sorbitol }+\mathrm{NADP}^{+} \\
\text {Aldose reductase } \\
\text { Sorbitol }+\mathrm{NAD} \rightleftharpoons \text { Fructose }+ \text { NADH }+\mathrm{H}^{+} \\
\text {Sorbitol dehydrogenase }
\end{gathered}
$$

These enzymatic reactions provide the basis for the synthesis of fructose from glucose in seminal vesicles [2] and lens $[16,5,4]$. The data of STEWART et al. [15] suggest that the synthesis of fructose from glucose in peripheral nerve occurs primarily in the Schwann cells. However, the presence of fructose and sorbitol in brain $[14,11]$, although in much lower concentrations than in peripheral nerve and spinal cord, suggests that the sorbitol pathway may also be operative in other cells of the nervous system.

GABBAY et al. [1] demonstrated a linear increase in nerve fructose levels with increasing blood sugar levels. This suggests that the plasma glucose concentration may be a regulating factor in fructose synthesis in neural tissue as it is in the synthesis of fructose in seminal vesicle [8].

Certain problems arose in the present study from the authors' reluctance to perform lumbar punctures solely to obtain cerebrospinal fluid samples for assay. Thus a comparison of plasma glucose and cerebrospinal fluid fructose concentrations in subjects who were fasting at the time of lumbar puncture was possible in only 23 instances. In this sub-group a significant relationship between plasma glucose and cerebrospinal fluid fructose could not be demonstrated although a general trend was apparent. However, the linear relationship between cerebrospinal fluid glucose and fructose concentrations observed in these studies (see Figure 2) and anticipated by HuBBaRD and RusséLL [3] are in keeping with the view that an increased glucose concentration in the perfusing blood leads to an increased level of fructose in neural tissues.

We have recently had the opportunity of assaying samples of cerebrospinal fluid from a patient recovering from non-ketotic hyperosmolar diabetic coma who had presented with a blood sugar in excess of $1200 \mathrm{mg} \%$ and multifocal Jacksonian seizures. As shown in Table 1 , the cerebrospinal fluid fructose declined with the decrease in cerebrospinal fluid glucose concentrations as predicted from the relationship depicted in Fig. 2.

The relationship between the fructose concentrations in specific neural tissues and cerebrospinal fluid remains to be determined, as does the manner in which fructose enters and leaves this fluid compartment. It would appear quite likely, however, that fluctuations in human cerebrospinal fluid fructose concentration mirror fluctuations in the neural con- centrations of this hexose. Viewed in this light, these data suggest that alterations in the activity of the sorbitol pathway may exist in the neural tissues of

\begin{tabular}{|c|c|c|c|c|}
\hline \multirow[b]{2}{*}{ Date } & \multicolumn{2}{|c|}{ Cerebrospinal Fluid } & \multicolumn{2}{|l|}{ Plasma } \\
\hline & $\begin{array}{l}\text { Glucose } \\
\mathrm{mg} \%\end{array}$ & $\begin{array}{l}\text { Fructose } \\
\mathrm{mg} \%\end{array}$ & $\begin{array}{l}\text { Glucose } \\
\mathrm{mg} \%\end{array}$ & $\begin{array}{l}\text { Fructose } \\
\mathrm{mg} \%\end{array}$ \\
\hline $5 / 25$ & 168 & 13.0 & 328 & 2.2 \\
\hline $6 / 6$ & 86 & 4.3 & 80 & $<2.0$ \\
\hline
\end{tabular}
patients with diabetes mellitus that are similar to those observed in animals with experimental diabetes.

Table 1.

In both instances samples were obtained approximately 3 hours postprandially.

Acknowledgements. The authors are indebted to MARY Ann Holzinger, Sandra Cornelius, and Carole Luby for their expert technical assistance, to Dr. G. Mitron SHY and Dr. WILMER ANDERsoN for the opportunity to examine specimens from their patients, and to Dr. F.D.W. LuKENs for his continued guidance.

\section{References}

[1] Gabbay, K.H., L. O. Merola and R.A. Fremd: Sorbitol pathway: presence in nerve and cord with substrate accumulation in diabetes. Science 151, 209 $210(1966)$

[2] Hers, H.G.: Le mécanisme de la formation du fructose seminal et du fructose foetal. Biochem. biophys. Acta 37, 127-138 (1960).

[3] Hubbard, R.S., and N.M. Russem: The fructose content of spinal fluid. J. biol. Chem. 119, 647-661 (1937).

[4] Kinoshita, J.H., S. FutterminaN, K. Satoh and L. O. Merola: Factors affecting the formation of sugar alcohols in ocular lens. Biochim. biophys. Acta 74, $340-350$ (1963).

[5] KUCK, J.: The formation of fructose in the ocular lens. Arch. Ophthal. 65, 840-846 (1961).

[6] Ktotzsor., H., and H.-U. Bergmeyer: In Methods of Enzymatic Analysis, ed. by H.-U. BERGMEYkR. Weinheim/Bergstr., Verlag Chemie, pp. 156-159, 1963.

[7] Mabry, C.C., J.D. GryboskI and E.A. KaraM: Rapid identification and measurement of mono- and oligosaccharides: An adaptation of high-voltage paper electrophoresis for sugars and its application to biologic materials. J. Lab. clin. Med. 817-830 (Nov. 1963 ).

[8] MaNN, T., and U. Parsons: Studie on the metabolism of semen. 6. Role of hormones. Effect of castration, hypophysectomy and diabetes. Relation between blood glucose and seminal fructose. Biochem. J. 46, $440-450(1950)$.

[9] Park, C.R., L.H. Johnson, J.H. Wright Jr. and H. BATSEL: Effect of insulin on transport of several hexoses and pentoses into cells of muscle and brain. Amer. J. Physiol. 191, 13-18 (1957).

[10] RoE, J.H.: A colorimetric method for the determination of fructose in blood and urine. J. biol. Chem. $107,15-22(1934)$.

[11] Sherman, W.R., and M.A. Stwwart: Identification of sorbitol in mammalian nerve. Biochem. and Biophys. Res. Communications 22, $492-497$ (1966).

[12] Surtir, I.: Sugars. In Chromatographic and Electrophoretic Techniques, Vol. I, Chromatography. New 
York, Interscience Publishers, Inc., pp. 246-260, (1960).

[13] Somogrr, M.: A method for the preparation of blood filtrates for the determination of sugar. J. biol. Chem. $86,655-663(1930)$.

[14] Stewart, M.A., and J. V. Passonneau: Identification of fructose in mammalian nerve. Biochem. and Biophys. Res. Communications 17, 536-541 (1964).

[15] - - and O.H. Lowry: Substrate changes in peri- pheral nerve during ischaemia and Wallerian degeneration. J. Neurochem. 12, $719-727$ (1965).

[16] Van Heyningen, R.: Formation of polyols by the lens of the rat with "sugar" cataract. Nature 184, $194-195$ (1959).

\section{H. LINTON WRAY}

George S. Cox Medical Research Inst.

Department of Medicine

University of Pennsylvania

Philadelphia / Ponns. / U.S.A. 